\title{
Aquifer System, Recharge-Discharge Zone and Groundwater Basin Boundary Mapping to Support Open and Transparent Water Data, Case Study: Karangkobar Groundwater Basin
}

\author{
Thomas Triadi Putranto ${ }^{1,2}$, Muhammad Iman Luthfi ${ }^{1}$, Nurakhmi Qadaryati $^{1{ }^{*}}{ }^{*}$, Narulita Santi ${ }^{1}$, and Wahju Krisna Hidajat ${ }^{1}$ \\ ${ }^{1}$ Geological Engineering, Engineering Faculty, Diponegoro University, Semarang - Indonesia \\ ${ }^{2}$ Graduate Program of Environmental Science, Diponegoro University, Semarang - Indonesia
}

\begin{abstract}
Sustainable groundwater management based on groundwater basin (GWB) must be equipped with comprehensive information including the characteristic of hydrogeology. This management method is very useful for governments to design some regulations, such as tax and conservation zone. Nowadays, not only the government but the public society can also have access to know this management. Open and transparent groundwater application needs sufficient data. Based on that issue, this research aims to provide the geological and hydrogeological conditions of GWB, define the aquifer configurations, and determine the groundwater recharge-discharge zones and the type of GWB boundary on Karangkobar GWB. The methods applied to the study are 1) mapping the geological and hydrogeological condition; 2) reconstruction of subsurface stratigraphic condition; and 3) overlay four parameters of the recharge-discharge zone. The Karangkobar GWB consists of the unconfined and confined aquifer of High Plain Aquifer, where the groundwater flows from north and east heading southward and westward. Seven boundary types bounded the Karangkobar GWB. The map can also support the open and transparent water data application system, it will also ease the party that will conduct an assessment to design regulation regarding the groundwater management.
\end{abstract}

Keywords: groundwater basin; boundary type; Karangkobar; recharge zone.

\section{Introduction}

Groundwater is a renewable resource, which is also vital for the human race, must be wisely managed based on the principle of sustainability. A suitable strategy that supports and in line with sustainability basis is by conducting groundwater management based on groundwater basin $[1,2]$. The state of California in the United States is one of the states that has successfully proclaimed an open and transparent Water Data Act [world economic forum]. In order to support the act, an integrated application system that provides the information on numerous data, including groundwater basin boundary. Delineation of groundwater basin boundary relies on a study of the aquifer and rechargedischarge zone. The main factor that controls a recharge zone is a hydrologic landscape of the aquifer system, while the water flow is dependent on climate, topography and the geologic framework [3]. The distribution of recharge can be estimated using a water level map, but the accuracy depends on the magnitude and distribution of the aquifer permeability [4].

Karangkobar Groundwater Basin (Karangkobar GWB) is 32,600 ha wide that covered Banjarnegara and Wonosobo administrative area [5, 6], shown in Fig. 1. Morphologically located on the highland, Karangkobar
GWB most likely is the High Plain Aquifer System [7], an aquifer system that is applied to hydrogeology exploration [8]. As one of the groundwater basin in Central Java Province, Karangkobar GWB is considered to be a lack of hydrogeological data. This research aims is to provide the geological and hydrogeological conditions of GWB, define the aquifer configurations, determining the groundwater recharge-discharge zones and the type of GWB boundary on Karangkobar GWB. This goal is also part of the initiation towards groundwater basin management in Karangkobar GWB.

\subsection{Regional geology}

The regional geology is referring to the Geological Map of Banjarnegara-Pekalongan [9]. The geological event that formed the sedimentary basin in this study area begins at early Cenozoic, the uplift on the north part of Java and later accompanied by an erosional event. The earlier formations are Rambatan Formation and Halang Formation, a product of the deep marine depositional environment. Stratigraphically, the Karangkobar GWB is composed by 9 lithological formations. Then sea level drop caused the shifting of the depositional environment into a bathyal to a transitional environment that deposited Damar Formation. During Plio-Pleistocene,

\footnotetext{
Corresponding author: nurakhmi@live.undip.ac.id
} 
another compressional phase took place and caused the reactivation of existing faults. Quaternary volcanic activity occurred during this time as well [10]. The formation distribution is shown in Fig. 2 and the description is provided in Table 1.

\subsection{Regional hydrogeology}

Based on the regional hydrogeology, Karangkobar GWB is divided into three areas based on groundwater availability and aquifer productivity. The first category is the intergranular aquifer system which has intermediate aquifer productivity and covers only a small area. The second category is the intergranular and fracture aquifer system, which is subdivided into a wide distribution area with intermediate productivity and local distribution area with a productive aquifer. The third category is the locally low productivity aquifer and rare groundwater.
The distribution is shown in Fig. 2.

Table 1. Restivity value of various rock types.

\begin{tabular}{|l|c|c|c|}
\hline \multirow{3}{*}{ Material } & \multicolumn{3}{|c|}{ Resistivity $(\Omega \mathrm{m})$} \\
\cline { 2 - 4 } & $\begin{array}{c}\text { Musset \& } \\
\text { Khan [11] }\end{array}$ & $\begin{array}{c}\text { Telford et.al } \\
{[12]}\end{array}$ & $\begin{array}{c}\text { Todd \& } \\
\text { Mays [12] }\end{array}$ \\
\hline Clay & $1-100$ & $1-100$ & $1-500$ \\
\hline Silt & $1-100$ & $3-70$ & - \\
\hline Sandstone & $1-10^{8}$ & $1-6,4 \times 10^{8}$ & $1-5 \times 10^{3}$ \\
\hline Sand & $5-5 \times 10^{3}$ & - & $1-10^{3}$ \\
\hline Limestone & $50-10^{7}$ & $50-10^{7}$ & $10^{2}-10^{6}$ \\
\hline Conglomerate & - & $2 \times 10^{3}-10^{4}$ & $10^{2}-10^{5}$ \\
\hline Lava & - & $100-5 \times 10^{4}$ & $10^{2}-10^{5}$ \\
\hline Andesite & - & $1,7 \times 10^{2}-$ & $10^{2}-10^{5}$ \\
& & $4,5 \times 10^{4}$ & \\
\hline Gabro & $10^{3}-10^{6}$ & $10^{3}-10^{6}$ & $10^{2}-10^{5}$ \\
\hline Basalt & $10-10^{7}$ & $10-1,3 \times 10^{7}$ & $10^{2}-10^{5}$ \\
\hline Breccia & - & - & $10^{2}-10^{5}$ \\
\hline Tuff & - & $2 \times 10^{2}-10^{3}$ & $10^{2}-10^{5}$ \\
\hline
\end{tabular}

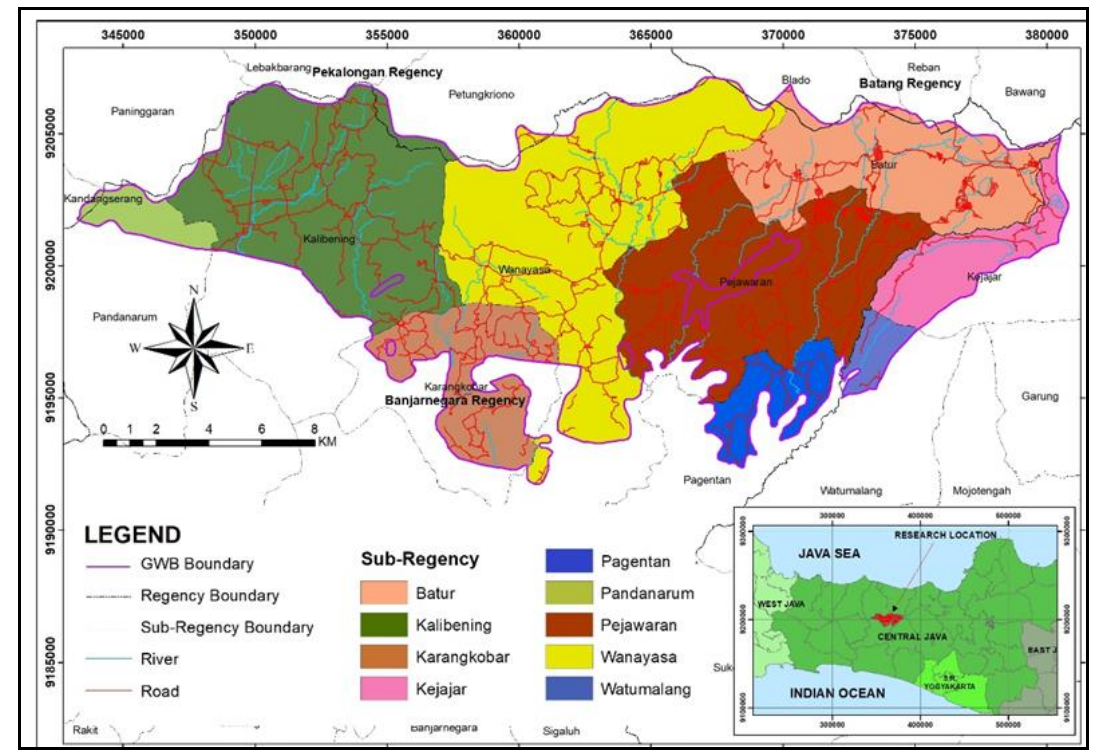

Fig. 1. Research area map, covers Banjarnegara and Wonosobo.

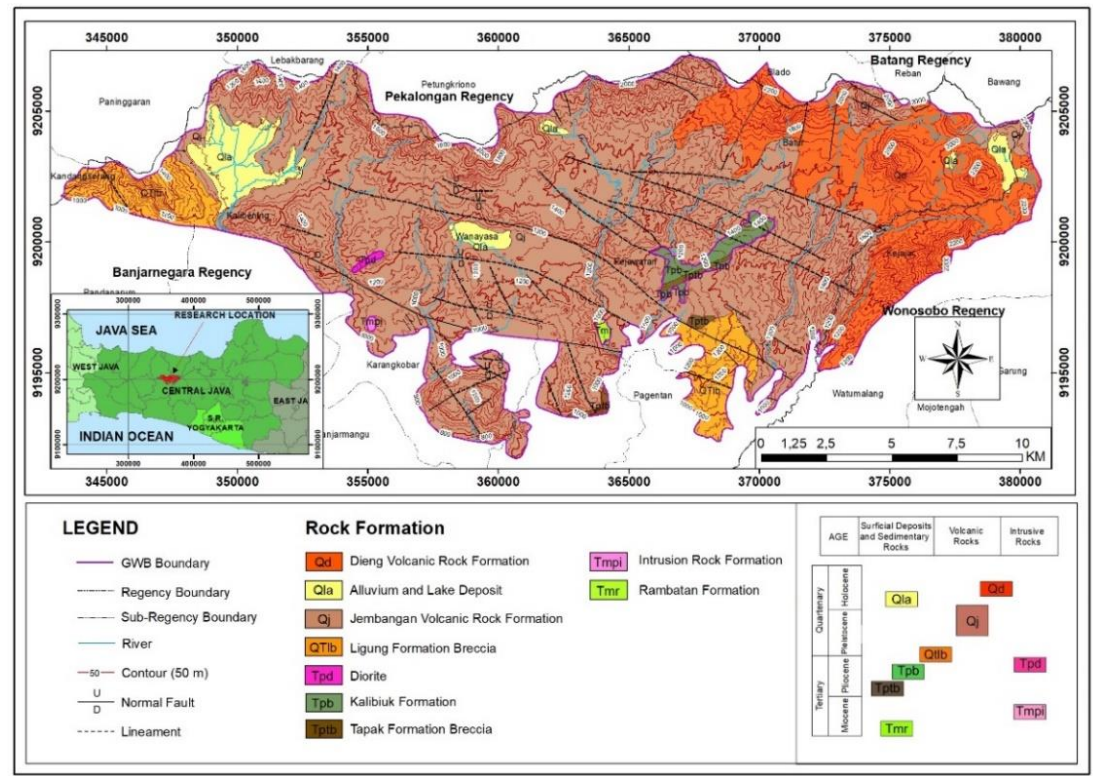

Fig. 2. Regional Geology Map of research area. 


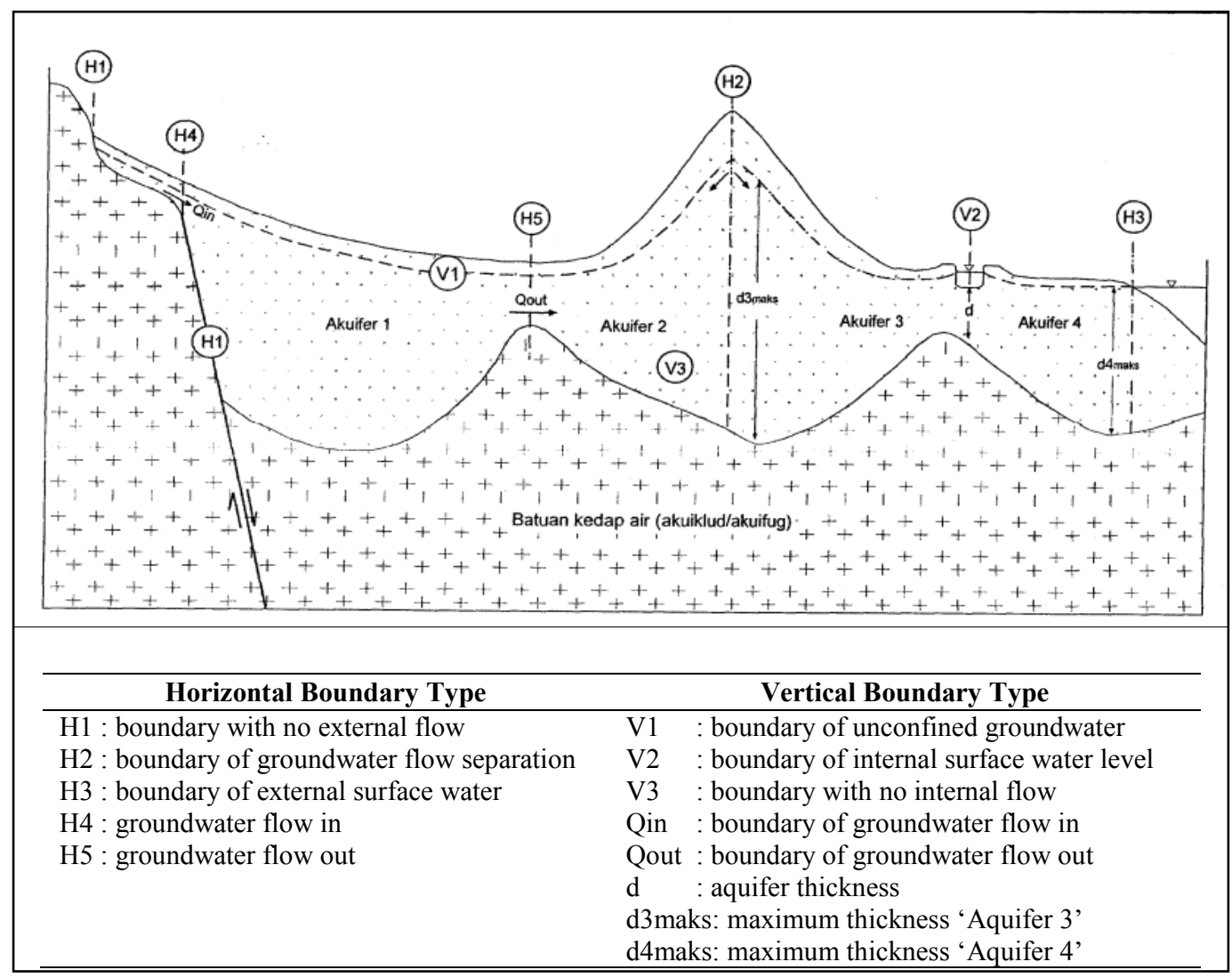

Fig. 3. Groundwater basin boundary types (Minister Regulation of Ministry of Energy and Mineral Resource No. 13/ 2009).

Table 2. Resistivity of lithological unit in Karangkobar GWB

\begin{tabular}{|c|c|}
\hline Resistivity ( $\mathbf{\Omega m})$ & Lithogical unit \\
\hline $30-700$ & Top soil \\
\hline $1-30$ & Tuff \\
\hline $20-70$ & Alluvial Deposit \\
\hline $30-80$ & Tuffaceous Sandstone \\
\hline $90-400$ & Tuffaceous Breccia \\
\hline
\end{tabular}

\subsection{Groundwater basin boundary type}

Basically, the groundwater basin is bounded by the hydrogeological aspect, controlled by geological condition and groundwater hydraulic, which usually is not synchronous with the government administrative boundary. The groundwater basin boundary actually might cross the border of regency or district, province, or even country. The government already issued the regulation about the basis of groundwater basin determination in Minister Regulation of Ministry of Energy and Mineral Resource No. 13/ 2009, which also mentioned the type of boundaries, shown in Fig. 3. A groundwater basin can be bounded by one or more boundary types with different hydraulic systems [9].

\section{Methodology}

\subsection{Field Observation}

Field observation is conducted, including rock description and groundwater level recording from a total of 98 observation location points that covers Karangkobar GWB, 54 points of it are the location springs. The groundwater level data is the input to build groundwater level and flow map.

\subsection{Digital Elevation Model Analysis}

The Digital Elevation Model (DEM) is classed based on its slope percentage in order to classify the topography within Karangkobar GWB. The stream pattern is also obtained from DEM that will be utilized to make a stream order map. The lower stream order means streams from upstream, whilst higher stream order show streams of downstream. The slope percentage map and stream orde map later will be one of the parameter input in determining the recharge-discharge zone.

\subsection{Subsurface stratigraphy reconstruction}

Lithostratigraphy and hydrostratigraphy, which is distributed subsurface, is visualized into a vertical section that is reconstructed from electrical sounding data measured in 2009 by the Ministry of Energy and Mineral Resource. Resistivity data from 24 measuring point is processed and converted into a lithology log based on the classification in Table 1. Six correlations are made from these lithology logs. 


\subsection{Recharge-discharge zone determination}

Basically, the groundwater flows within a groundwater basin most likely begin from the recharge area to the discharge area. The recharge area is part of watershed where the groundwater flows away from the groundwater level, whilst the discharge area is when the groundwater flow towards groundwater level [13]. The characteristics of recharge area [11] are: 1) having a vertically downward groundwater flow, 2) area where water surface infiltrates through topsoil to groundwater level, 3) has deep phreatic water level and relatively lower than piezometric surface in normal condition, 4) has low chemical constituent, and 5) has younger groundwater age. Recharge zone determination can be conducted by statistics analysis [14] and spatial analysis [15]. Some of the applications of the recharge area zone are to estimate the groundwater time travel [16] and to obtain the chemical properties of groundwater [17]. Certain areas that can serve as recharge area are volcanic cone and edifices, karst area where limestone dissolution is most intense, and upstream area that has outcrop of a confined aquifer.

This procedure is referring to Ministerial Regulation of Ministry of Energy and Mineral Resource No. 31/
2018. Hence, the determination is conducted by overlying four maps that contain the parameter to determine the recharge and discharge zone. The first layer is the morphometry map that represents the topography of the research area, the second layer is spring location point, the third layer is the stream order map and the fourth is the groundwater level map.

\section{Result}

\subsection{Morphometry map}

Karangkobar GWB is divided into six class of slope percentage, which are flat $(0 \%-2 \%)$, gently slope $(3 \%$ $7 \%$ ), sloping (8\%-13\%), moderately steep (14\%-20\%), steep $(21 \%-55 \%)$ and very steep $(56 \%-140 \%)$. From the shown in Fig. 4, Karangkobar GWB is dominated by gently slope and steep topography.

There are five stream orders (order 1 to order 5) in Karangkobar GWB. The stream order map is shown in Fig. 5, where it also can identify two stream patterns which are, dendritic and radial pattern. The radial pattern is identified relatively on the northern part of the GWB.

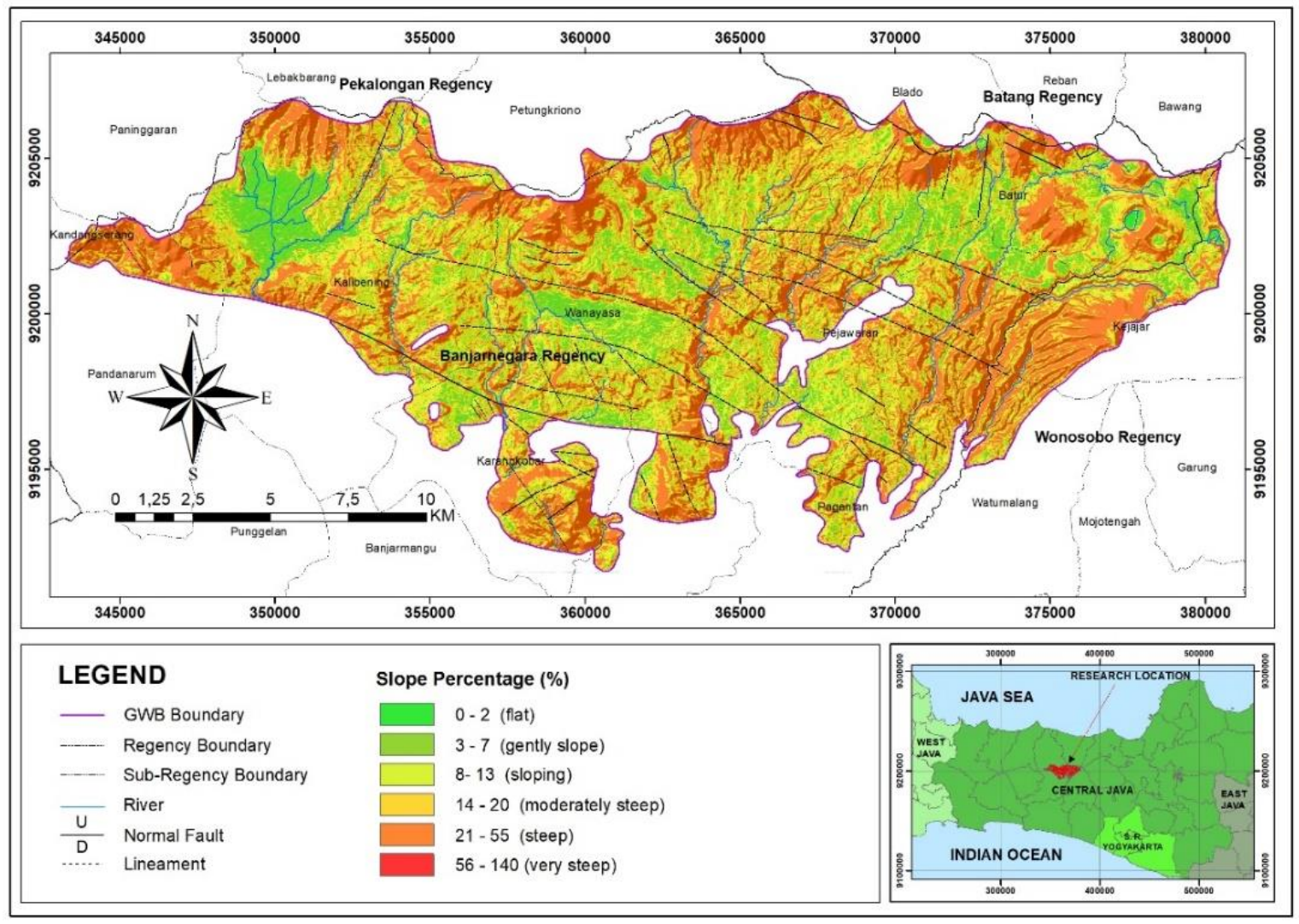

Fig. 4. Geomorphometry map of Karangkobar GWB. 


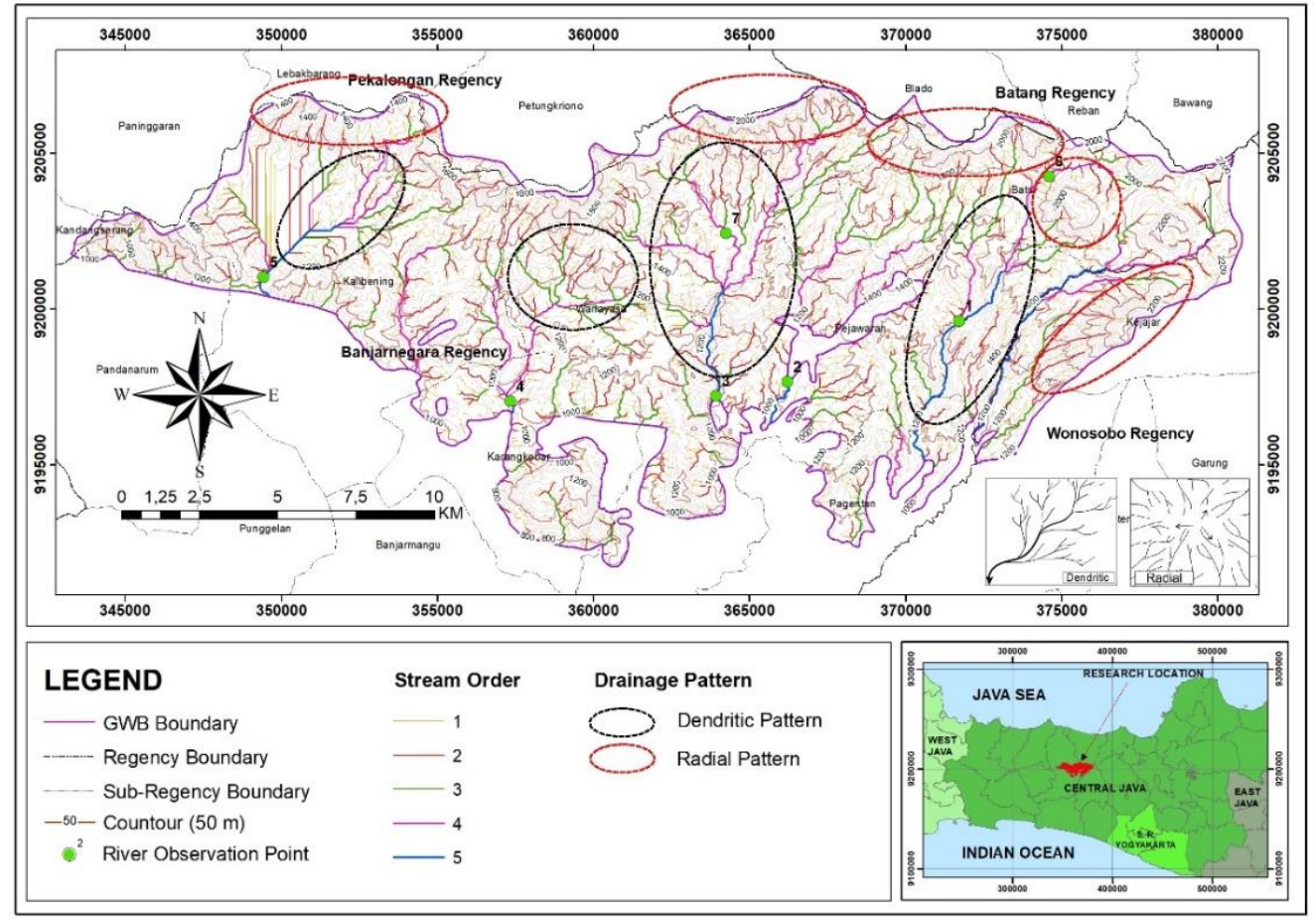

Fig. 5. Stream order and drainage pattern of Karangkobar GWB.

\subsection{Subsurface stratigraphy}

The resistivity $\log$ from 24 measuring points obtained the information that there are three lithological units, which are tuffaceous sandstone, tuff, and tuffaceous breccia. The list is shown in Table 2. In general, the vertical sections show that the distribution of tuffaceous breccia is thinning eastward (Fig. 6), and thick on the western part research area (Fig. 7).

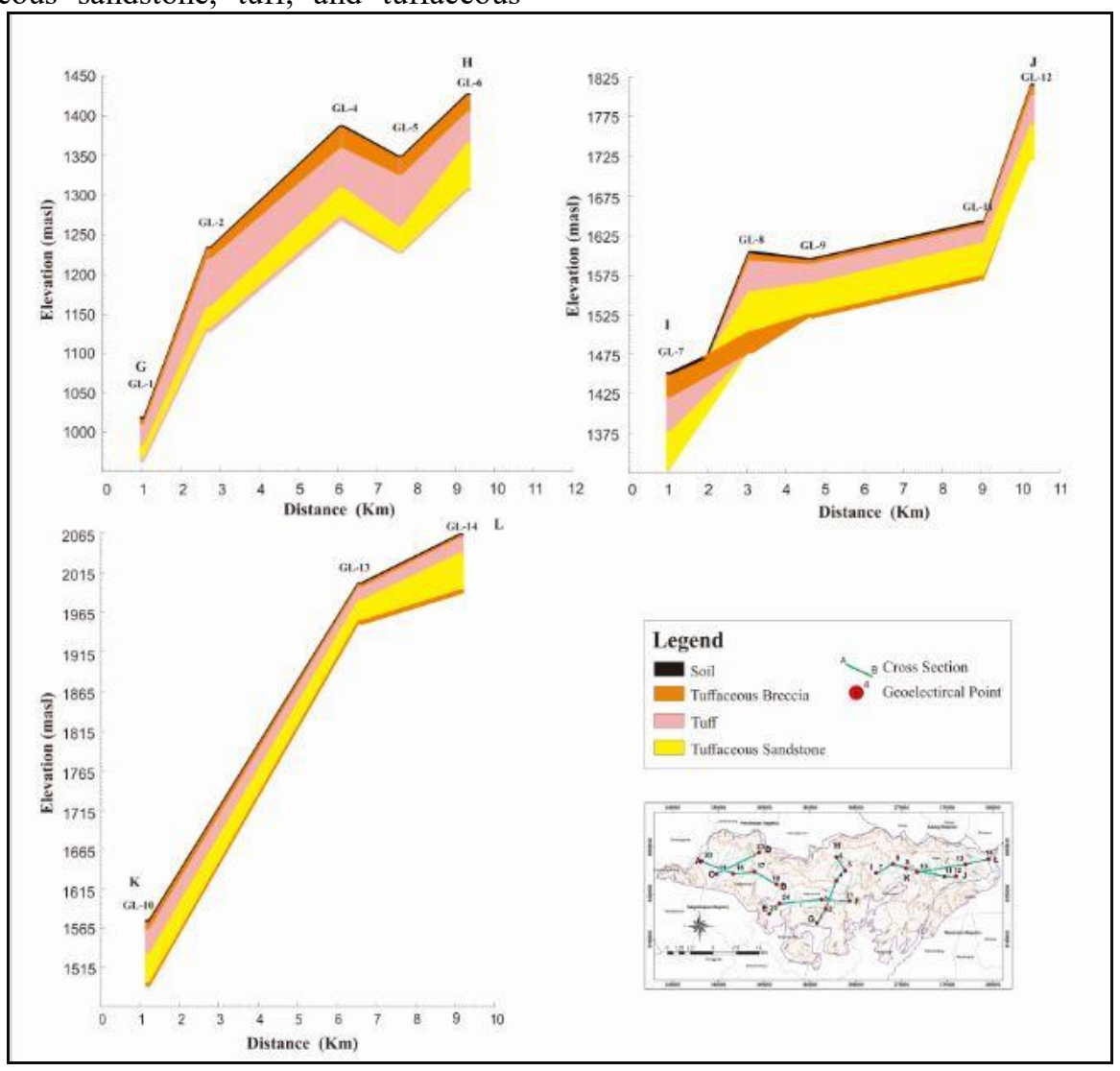

Fig. 6. Lithostratigraphic correlation section represent the eastern part of Karangkobar GWB. 


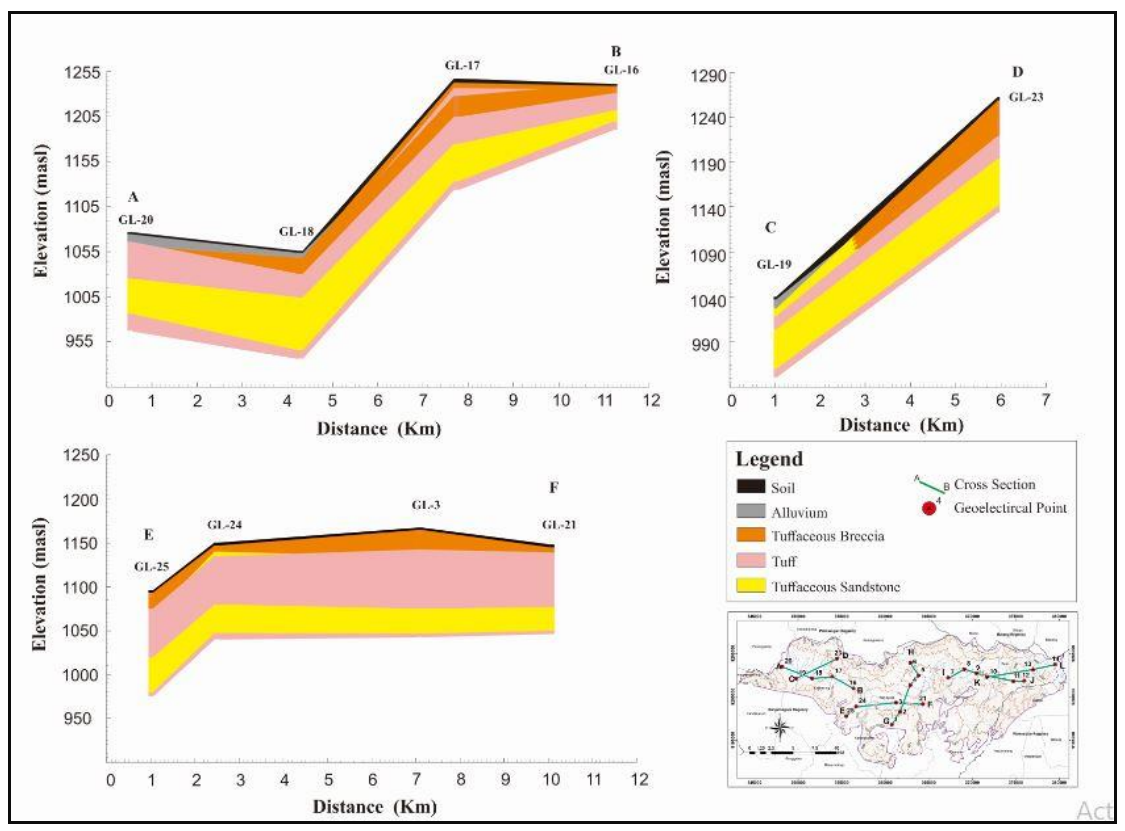

Fig. 7. Lithostratigraphic correlation section represent the western part of Karangkobar GWB.

\subsection{Hydrogeology}

Two types of spring are identified in Karangkobar GWB, which are depression spring and contact spring. The depression springs are mostly located in the northern part of the research area, especially around Kalibening (observation point no.85, 47, 49). The contact springs are located on the area that is part of the cone hill, such as in Batur (observation point no. $70,71,73,65$ ).
Based on the groundwater level, there are two zonations in this research area: deep groundwater level $(>10 \mathrm{~m})$ and shallow groundwater level $(0-10 \mathrm{~m})$. The groundwater flow map of Karangkobar GWB (Fig. 8) shows that the highest level of an unconfined aquifer is $2,100 \mathrm{~m}$ above sea level and the lowest level is at $800 \mathrm{~m}$ above sea level. The groundwater flow pattern revealed that the groundwater flows from north and east heading southward and westward.

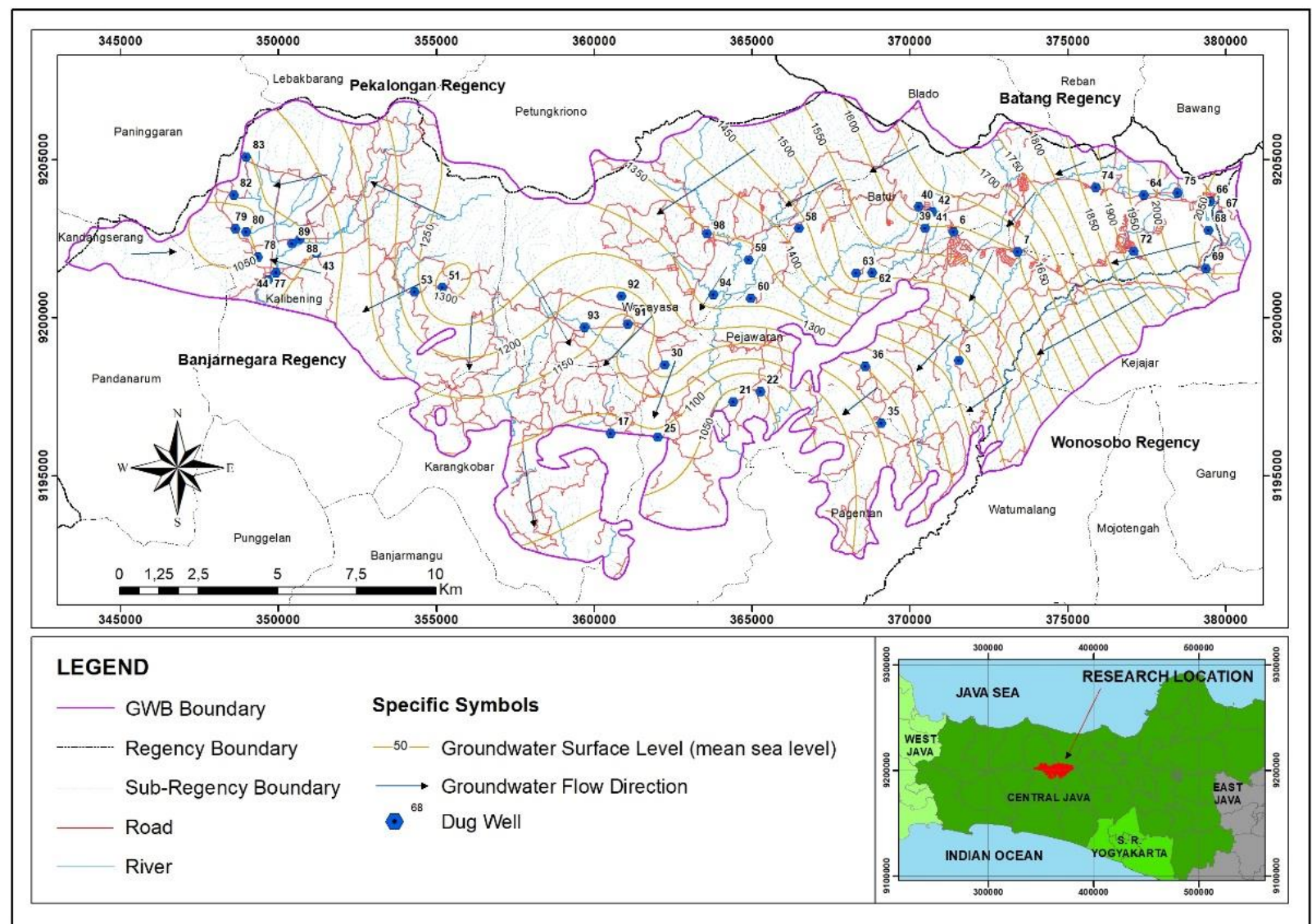

Fig. 8. Groundwater flow map of Karangkobar GWB. 


\subsection{Hydrostratigraphy}

Hydrostratigraphy is actually the derivative lithology $\log$. The units are based on the rock characteristic and resistivity, also groundwater level. There are four hydrostratigraphic units within the research area, which are vadose zone, unconfined zone, aquiclude, and confined aquifer. The unconfined aquifer is most likely from tuffaceous breccia and tuffaceous sandstone, aquiclude is from an impermeable layer of tuff, and the confined aquifer is the tuffaceous sandstone under the tuff layer. Vertical sections of hydrostratigraphy are shown in Fig. 9 \& 10.

\subsection{Recharge and discharge zonation}

Based on the groundwater flow that has direction flow from north and northeast towards south and southwest, it is clear to see that the pattern is parallel to the topography, where higher topography is on the north and relatively low topography is in the southern part of the research area. In other words, water in an unconfined aquifer is mostly infiltrated and recharged from the north and northeast part of Karangkobar GWB.

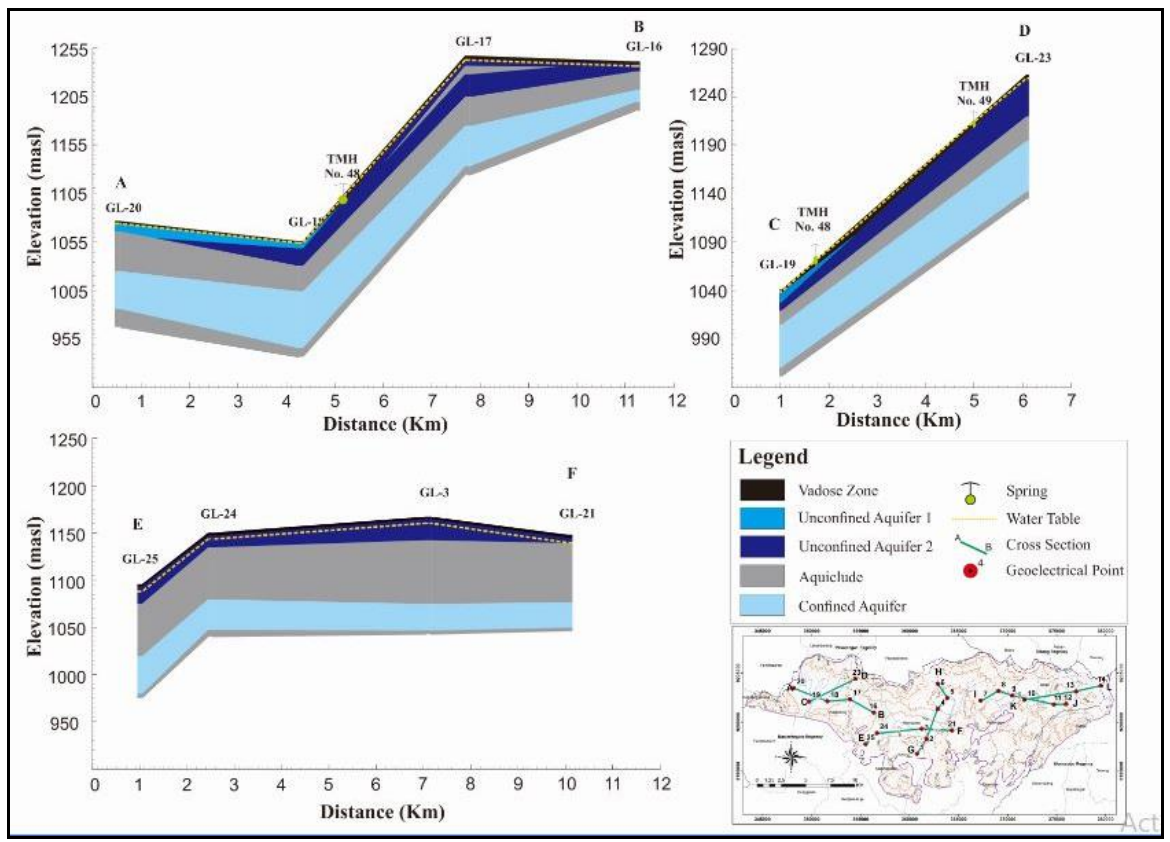

Fig. 9. Hydrostratigraphy correlation section: A-B, C-D and E-F.

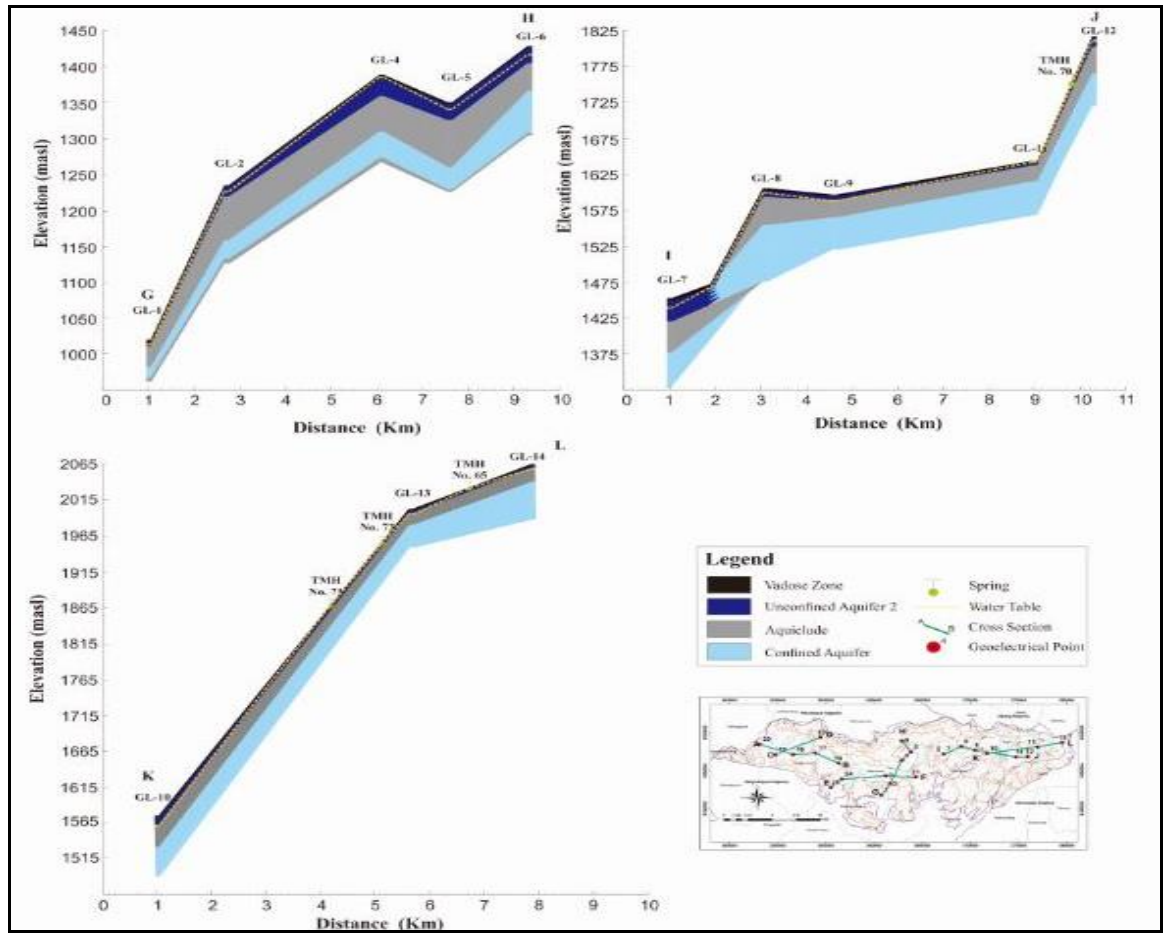

Fig 10. Hydrostratigraphy correlation section: G-H, I-J and K-L. 


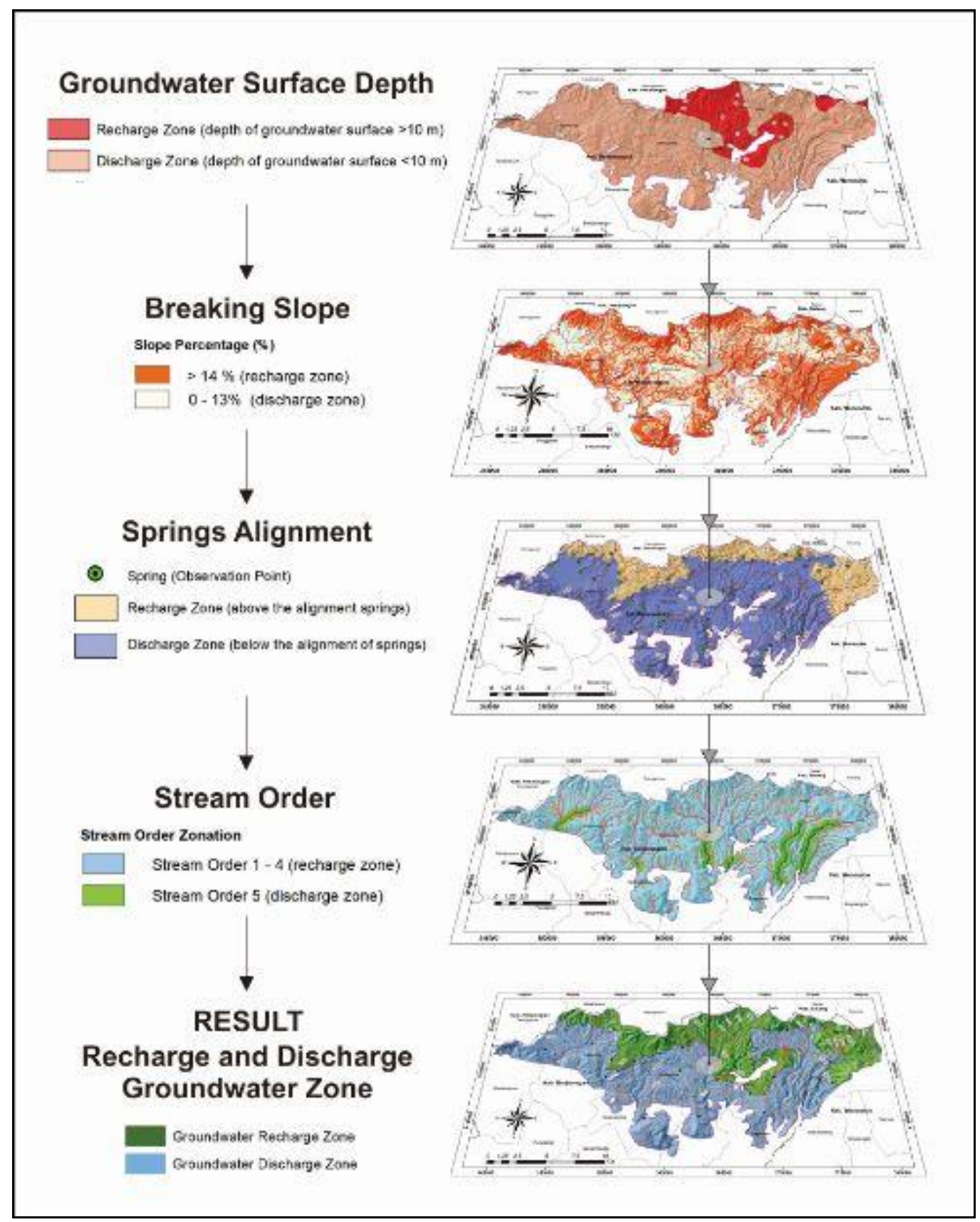

Fig. 11. Overlay of four parameter maps of recharge-discharge zone in Karangkobar GWB: groundwater surface depth map, breaking slope map, spring alignment map and stream order map.

The breaking slope between moderately steep (slope percentage $>14 \%$ ) and flat topography (slope percentage $0 \%-13 \%$ ) is the parameter input for the map overlaying process. As for the stream order, the first to fourth order will consider the area as recharge zone and fifth order contribute as discharge area, giving $500 \mathrm{~m}$ radius area from the stream. Spring alignment may indicate the boundary between recharge and discharge, with the consideration that there will only be a slight distance between the boundary and the alignment.

The recharge zone is the result of two combinations: 1) intersection of deep groundwater level zone, the first to third stream order and steep slope; 2) intersection of the area above spring alignment, the first to third stream order and steep slope. The discharge zone will cover the area where the two combinations do not accomplish.

All the parameter maps are shown in Fig. 11, with the recharge and discharge groundwater zona map as the result. The recharge area relatively took a small part in the northern border compared to the discharge area that covers the western and southern part of Karangkobar GWB 


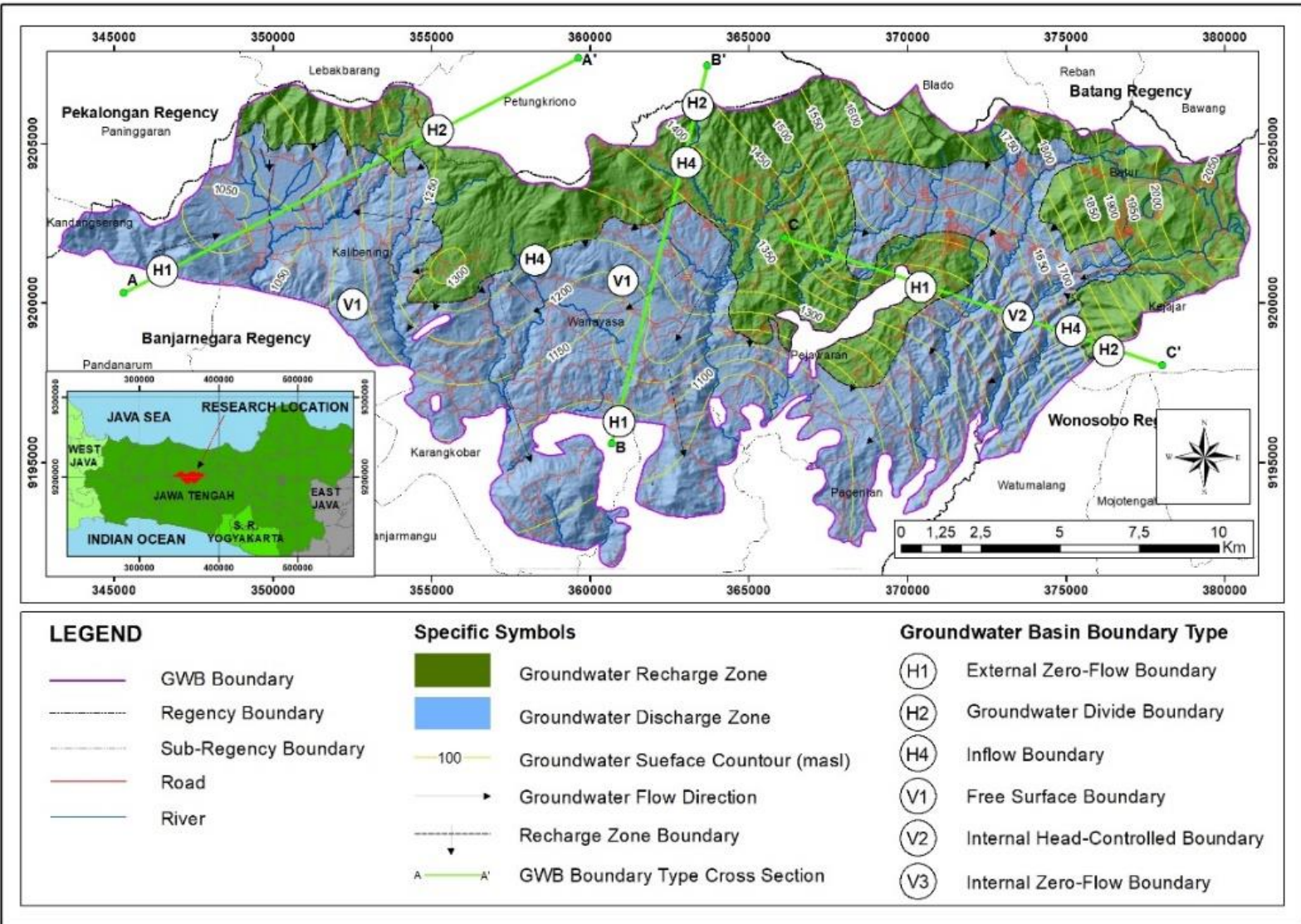

Fig. 12. Groundwater basin boundary on recharge and discharge zone map of Karangkobar GWB.

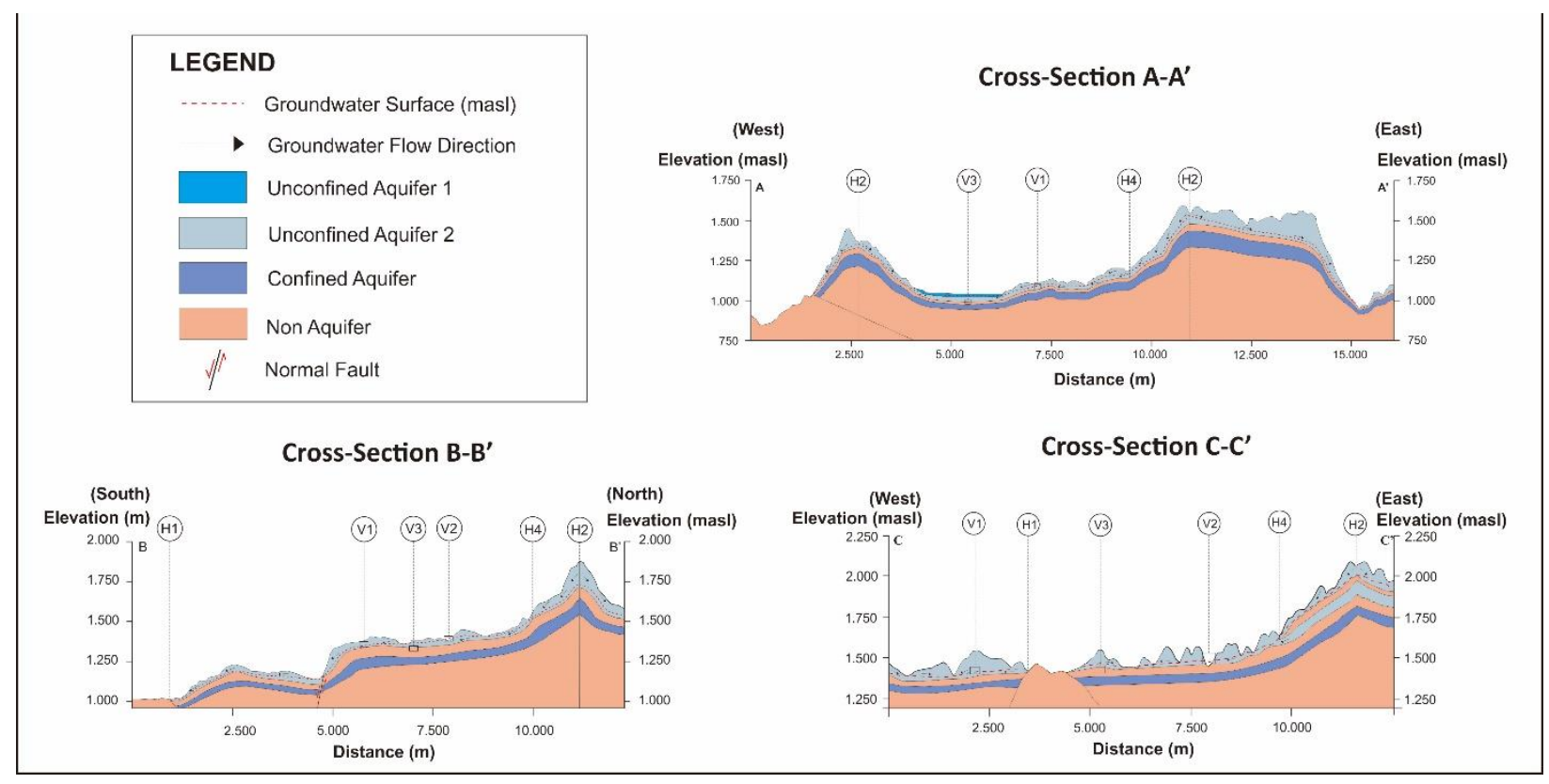

Fig. 13. Groundwater basin boundary type determination in Karangkobar GWB.

\section{Discussion}

\subsection{Aquifer system}

Karangkobar GWB has two aquifer systems, the unconfined aquifer and the confined aquifer. Considering the data availability of this study, it is only adequate to analyze the unconfined aquifer system. The lithology of the unconfined aquifer in Karangkobar GWB dominantly consists of tuffaceous breccia, and tuffaceous sandstone locally. Regionally, these lithologies are part of the Api Jembangan Volcanic Formation. The porosity types of the aquifer are intergranular porosity and fracture porosity. 
In terms of geometry, the unconfined aquifer has various thickness all over the Karangkobar GWB. The maximum thickness $(30 \mathrm{~m}-43 \mathrm{~m})$ is found located in Wanayasa Area (at the center part of GWB), and the thinnest is located in Kalibening Area (at the west part of GWB) even though aquifer with minimum thickness range is widely spread on the east part of GWB (Karangkobar, Pagentan, Pandanarum and Batur Area).

\subsection{Karangkobar GWB boundary types}

Considering the hydrostratigraphy units and rechargedischarge zone, Karangkobar GWB is bounded by three horizontal boundaries and three vertical boundaries. The horizontal boundaries are: 1) boundary with no external flow (H1) which are on the outer part of the discharge zone; 2) boundary of groundwater flow separation (H2) which are located on the outer part of recharge area; 3 ) boundary of groundwater input (H4) where mostly found on the contact between recharge and discharge zone. The vertical boundaries are: 1) boundary of unconfined groundwater level (V1); 2) boundary of surface water (V2); 3) boundary without internal flow (V3). The distribution is displayed in the Karangkobar GWB boundary map (Fig. 12) and the determination of these boundaries is shown from the three represented cross section in Fig. 13.

The groundwater basin boundary map will be very useful to determine which area has favourable groundwater system and which one has the discouraging one. The map can also support the open and transparent water data application system. Thus, it will ease the party that will conduct an assessment to design regulation regarding the groundwater management, for example, tax and water pumping.

\section{Conclusion}

Karangkobar GWB is divided into 7 geomorphological units, composed of three lithological units (tuffaceous breccia, tuffaceous sandstone, and tuff); alluvial deposit and top soil. In terms of hydrostratigraphic, Karangkobar GWB consist of: 1) unconfined aquifer composed of tuffaceous breccia and locally tuffaceous sandstone where the groundwater flows from north and northeast to south and southwest, 2) confined aquifer of tuffaceous sandstone, and 3) aquiclude composed of tuff. The recharge zone of Karangkobar GWB is located along the northern border of the GWB, including Kalibening, Wanayasa, Batur, Pejawaran and Kejajar Area. There are six boundary types that bounded Karangkobar GWB, which are H1, H2, H4, V1, V2 and V3. The groundwater basin boundary data will be very useful to support an open and transparent water data in Karangkobar GWB, but must be updated periodically, at least every 5 years.

\section{References}

1. H. Hendrayana, A Concept Approach of Total Groundwater Basin Management, International Symposium on Natural Resource and Environmental
Management, held in the framework of the 43rd Anniversary of UPN "Veteran" Jogyakarta (2002)

2. H. Hendrayana, D.P.E Putra, Groundwater Control "A Thought", Geological Engineering - UGM, Yogyakarta (2008)

3. T.C. Winter, The concept of hydrologic landscapes, J. Am. Water Resour. Assoc. 37, 225-349 (2001)

4. W. Sanford, Recharge and Groundwater Models: An Overview, Hydrogeol. Jour. 10, 110-120 (2002)

5. BAPPEDA Kabupaten Banjarnegara, Administrative Region Map and Land Use Map, (unpublished, 2017)

6. BAPPEDA Kabupaten Wonosobo, Map of Administrative Region Map of Land Use, (unpublished, 2017)

7. D.K. Todd, Groundwater Hydrogeology, 3rd ed., John Willey and Sons. New York (2005)

8. E.D.G. Tag, F.J. Helms, N.C. Krothe, R.R. Luckey, J.B. Weeks, Geohydrology of the High Plain Aquifer in Parts of Colorado, Kansas, Nebraska, New Mexico, Oklahoma, South Dakota, Texas and Wyoming, US Geological Survey Professional Paper, 1400-B (1984)

9. W.H. Condon, L. Pardyanto, K.B. Ketner, T.C. Amin, S. Gafoer, H. Samodra, Geological Map of Banjarnegara and Pekalongan Sheets (1408-4, 14091), scale 1: 100,000, Central Java, Pusat Pengembangan dan Penelitian Geologi, Bandung (1996)

10. D.A Nainggolan, Underwater Geological Structure of Pekalongan and Surrounding Areas Based on Analysis of Heavy Anomalies and Magnets, Jur. S.D. Geol 2, 19 (2009)

11. Danaryanto, H. Titomiharjo, H. Setiadi, Y. Siagian, Collection of Groundwater Management Technical Guidelines, Badan Geologi, Bandung (2007)

12. A.E. Mussett, M.A. Khan, Looking into the Earth. An Introduction to Geological Geophysics, Cambridge University Press, xxi +470 (2000)

13. W.M Telford, L.P. Geldart, R.E Sheriff, Applied Geophysics 2nd Edition, Cambridge University Press, Cambridge (2004)

14. N.C. Mondal, V.S. Singh, A New Approach to Delineate the Groundwater Recharge Zone in Hard Rock Terrain, Current Sci 87(5) (2004)

15. A.G. Chachadi, New Indicator Based Method SALDIT for Delineation of Natural Groundwater Recharge Areas, Aquatic Proc. 4, 649-659 (2004)

16. G.F. Lee, A.J. Lee, Water Quality Aspects of Groundwater Recharge: Chemical Characteristics of Recharge Wates and Long-Term Liabilities of Recharge Projects, Proc. Second Intl. Symp. on Artificial Recharge of Ground Water, 502-511 (1995)

17. X. Cong, Z. Su, T. Wang, Research on Characteristics of Groundwater Recharge in the Weishin Irrigated District Based on a Bromide Tracer, MDPI Journ.

18. R.J. Kodoatie, Introduction to Hydrogeology, Andi: Yogyakarta (1996) 